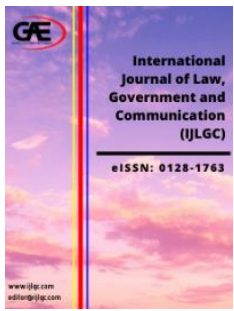

\author{
INTERNATIONAL JOURNAL OF LAW, \\ GOVERNMENT AND COMMUNICATION \\ (IJLGC) \\ $\underline{\text { www.ijlgc.com }}$
}

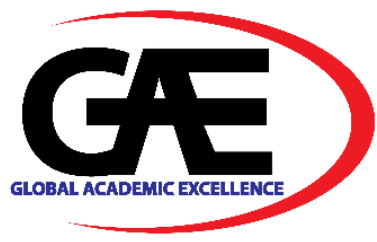

\title{
REGULATORY FRAMEWORK AND LEGAL CHALLENGES IN DIGITALIZATION OF ISLAMIC FINANCE
}

\author{
Nor 'Adha Ab Hamid" ${ }^{1}$ Ahmad Yani Ismail ${ }^{2 *}$, Tuan Nurhafiza Raja Abdul Aziz ${ }^{3}$
}

1 Associate Professor, Faculty of Syariah and Law, Kolej Universiti Islam Antarabangsa Selangor (KUIS), Bandar Seri Putra, 43000 Kajang Selangor

Email: noradha@kuis.edu.my

2 Lecturer, Faculty of Management and Muamalah, Kolej Universiti Islam Antarabangsa Selangor (KUIS)

Email: ahmadyani@kuis.edu.my

3 Lecturer, Faculty of Syariah and Law, Kolej Universiti Islam Antarabangsa Selangor (KUIS)

* Corresponding Author

\section{Article Info:}

Article history:

Received date: 15.04 .2021

Revised date: 15.05 .2021

Accepted date: 31.05 .2021

Published date: 15.06 .2021

\section{To cite this document:}

Ab Hamid, N., Ismail, A. Y., \& Aziz, T. N. R. A. (2021). Regulatory Framework And Legal Challenges In Digitalization Of Islamic Finance. International Journal of Law, Government and Communication, 6 (24), 59-75.

DOI: $10.35631 /$ IJLGC.624004.

This work is licensed under $\mathrm{CC}$ BY 4.0

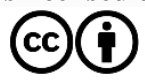

\begin{abstract}
:
This article analyses regulatory and legal challenges that may subsist in Malaysia's Islamic Finance digitalization moves. The country's finance industry regulators have been proactive in digitalizing the dual finance industry. The regulators have announced relevant frameworks since 2016 to support and spur digitalization development. This investigation employs a qualitative research method to achieve the objective. Despite bold initiatives, the authors argued the issues require comprehensive attention by the regulatory authorities. Past researchers have identified the issues. In this research, the authors expand the discussions on the identified issues.
\end{abstract}

Keywords:

Islamic Finance, Digitalization, Regulatory, Legal, Fintech

\section{Introduction}

Islamic Banking and Finance (IBF) industry continues to grow for three consecutive years registering USD 2.44 trillion in total worth in 2019, representing an 11.4 percent increase from USD 2.19 trillion in 2018 (Islamic Finance Development Report, 2019). The industry grew 9.6 Copyright (C) GLOBAL ACADEMIC EXCELLENCE (M) SDN BHD - All rights reserved 


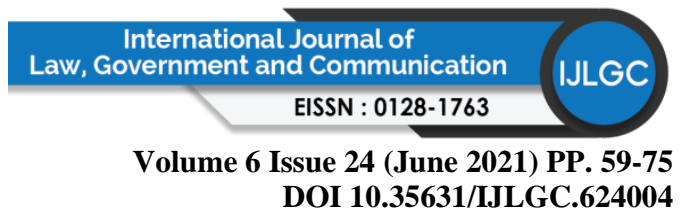

percent from 2017 to 2018. The above is supported by its Islamic banking sector's commendable performance, which recorded a 12.7 percent increase in 2019 (USD 1,765.8 trillion) compared to 0.9 percent in 2018 (USD 1,571.3 trillion). The Islamic Capital Market also contributes to the industry's growth with a 3.6 percent increase outperforming the Islamic banking sector.

The digitalization era resulting from the 4th Industrial Revolution (4th IR) has also changed the landscape's IBF industry. Relevant global governments and authorities have commenced digitalization initiatives to expand the respective IBF industry further. One of the critical strategies to materialize Indonesia's vision to become the global Islamic economy's nucleus is to strengthen its digital economy. The country's vision is highlighted in the Masterplan for Indonesia Islamic Financial Architecture launched in 2016 (Islamic Finance Development Report 2019). Following the National Committee for Islamic Finance establishment, a Masterplan for Indonesia Islamic Economic 2019-2024 has been produced stating Indonesia's plan for the five years. As a result, efforts have been initiated to establish online halal marketplaces that allow users to inspect products with halal certification numbers. Additionally, shariah-compliant Islamic digital payments platform for transactions including food and beverages, electricity, fuel, and other necessities are also initiated.

Via its central bank, Bahrain has announced a regulatory sandbox in 2017 and has approved 35 companies for the sandbox. Before launching the sandbox, a dedicated Fintech \& Innovation Unit was established at the Central Bank of Bahrain to conduct a study and suggest policy action. Consequentially, the unit is instrumental in developing Bahrain's financial technology (fintech) ecosystem with support from private and public organizations. The need for international regulatory harmonization pushed the Fintech \& Innovation unit to collaborate with global regulators. In 2020, Bahrain's central bank announced a digital financial advisory named robo-advisory, incorporating rules and guidelines on crypto-assets services. To assist banks and minimize their operational cost, the central bank has also introduced an e-Know Your Customer (e-KYC) solution, which will expedite the opening of new accounts.

As one of the global leading Islamic Finance markets, Malaysia is aware of the need to make the most digitalization initiatives' opportunities. In terms of readiness, Malaysia ranked $31^{\text {st }}$ (out of 139 countries in the world) by the World Economic Forum's Network Readiness Index (IMF, 2020). The index measures a country's usage of information and communication technologies. To provide an impetus for the growth and development of fintech companies in Malaysia, the Malaysia Digital Economic Corporation (MDEC) launched the Fintech Booster in August 2020. The Fintech Booster program is a collaboration between MDEC and the Central Bank of Malaysia to assist Malaysia-based fintech companies in developing innovative products and services by extending their understanding of legal, compliance, and regulatory requirements. Fintech, being one of the core components of digitalization, has been identified as one of the technologies that can spur the financial industry, including Islamic Finance (CXOToday, 2020). MDEC, a government agency, has been tasked to create a vibrant fintech ecosystem in Malaysia and has engaged with technology-savvy newly established companies, funders, and international innovators. They aspire to position Malaysia's Islamic Finance as a vital fintech nucleus (MDEC, 2020). 


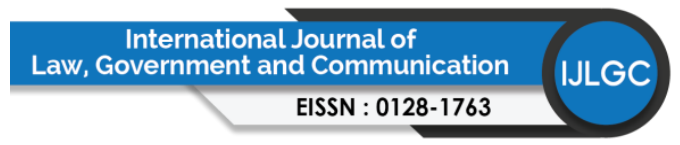

Volume 6 Issue 24 (June 2021) PP. 59-75

DOI 10.35631/IJLGC.624004

In addition to the Fintech Booster program, MDEC has also implemented the following initiatives:

1. The Orbit - a co-sharing space that provides domestic and international fintech companies to communicate with industry players to facilitate solution development and market entry.

2. FinTech Academy - MDEC collaborates with the Institute of Higher Education to provide lectures and modules on fintech. Together with the Central Bank of Malaysia and Securities Commission Malaysia, MDEC conducts quarterly regulatory boot camps.

3. Accelerators - via Accelerator initiatives, MDEC provides fintech companies with opportunities for domestic and international investments.

4. Financial Innovation Lab - partnering United Nations Capital Development Fund (UNCDF) and Central Bank of Malaysia, MDEC established Financial Innovation Lab intending to speed up innovation in digital financial services.

The above initiatives are on top of the Central Bank of Malaysia's numerous efforts, indicating Malaysia's commitment to the financial sector's digital transformation. An internal Fintech Working Group was established in 2016 and launched a regulatory Fintech Sandbox in the same year (Central Bank of Malaysia, 2020). The sandbox allows the pilot project for fintech solutions in a live environment and within the ambit of regulatory requirements. In the year 2020, the Central Bank of Malaysia has issued an e-KYC policy document to allow the opening of accounts and other related transactions to be conducted digitally without the customers being present at the bank. E-KYC is vital for bridging the gap that hinders digital banking development as it would reduce costs for customers and banks. It is also a significant step in establishing a virtual banking framework (Fintech News, 2020). In brief, the Central Bank of Malaysia has been very proactive in nurturing sufficient regulations to stimulate digitalization and innovation in the financial sector.

Malaysia's Islamic banking players are also committed to exploiting the Centra Bank of Malaysia's digital transformation move. Maybank, for example, aspires to be the choice digital bank with numerous initiatives. They include a cashless payment solution using Quick Response (QR) code and strategic partnership with Grab, an e-hailing, food delivery, and payment solutions company, to accelerate the acceptance and usage of cashless payment. Bank Islam Malaysia Berhad, in 2017, has announced its digital transformation with collaboration with Cognizant to implement initial works of transformation in its banking platform (TechBarrista, 2017). The bank is also committed to set up a new division to offer digital banking products in 2021 (The Star, 2020). RHB Islamic Bank Berhad, in 2018, reported developing an e-commerce financing platform to cater to the need of digital entrepreneurs (NST, 2018).

\section{Digitalization of Islamic Finance}

Digitalization of Islamic Finance refers to the digitization of all the standard Islamic Finance products and services previously offered at the bank's building (Ab Razak, Mohd Dali \& Abdull Manaf, 2019). It means the regular banking products and services are digitized and accessible online without customers going to any banking branches. The products and services are digitized using technologies including big data, artificial intelligence, robotics, blockchain, cryptocurrency, Internet of Things (IoT), and smartphones (Ab Razak et al., 2019). The use of such technologies to digitize Islamic Finance offerings and business processes is also termed 


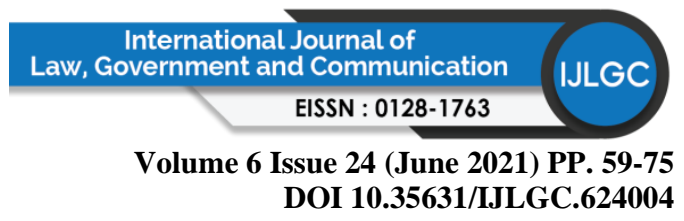

as fintech and Islamic fintech in Islamic Finance (Global Islamic Finance Report, 2017). Starting with the introduction of credit cards, auto teller machines, electronic stock trading, and internet banking (Global Islamic Finance Report, 2017), the birth of the $4^{\text {th }}$ Industrial Revolution has further accelerated the use of such technologies in the financial industry introduction of blockchain technology.

At the 2019 World Blockchain Summit in Kuala Lumpur, Malaysia, Datuk Dr. Mohd Daud Bakar boldly stated that the only way for Islamic Finance to be in the same playing field with conventional finance is via fintech (blockchain). He added that the technology could elevate Islamic Finance and capture the global financial industry's competitive market share as capitalization and operational costs are greatly minimized.

Islamic Finance, with shariah compliance at the core of its operation, rules that all of its offerings, operations, and activities must not contradict with shariah. The application of technologies in Islamic Finance products and services, as well as banking operations, is allowed as long as it does not contradict with shariah (Ab Razak et al., 2019). Hence, the digitalization transformation of Islamic Finance has no shariah issues provided that all elements of shariah are complied with.

\section{The Landscape of Digitalization}

The application of technologies in the finance industry, including Islamic Finance, can be generally categorized into:
a. Payments
b. $\quad$ Clearing and settlement
c. Deposits
d. Lending/Financing and capital raising;
e. Insurance/Takaful;
f. Investment management; and
g. Market support

\section{Payments, Clearing, And Settlement}

This category sees applying technologies in credit card, debit card, mobile banking, e-money, e-wallet, smartphones, and Quick Response (QR) codes. More and more transactions can be settled using an e-wallet available on smartphones. Some Islamic banks, including Maybank Islamic Berhad, provide alternative payment methods using its QRPayBiz. Some non-bank fintech companies have also offered e-wallet such as Boost, Mpay, Grabpay, and Touch' N Go e-wallet. Remittances services have also witnessed non-bank fintech companies offering the service such as TransferWise Malaysia and MoneyMatch.

\section{Deposits, Lending, Financing, And Capital Raising}

These services are generally the core of banking services. To date, Malaysia has no full-fledged digital bank. Nevertheless, the Central Bank of Malaysia has announced the opening of digital bank license applications after finalizing the regulatory licensing framework for digital banks by the end of 2020 (Lexology, 2021). The Central Bank of Malaysia plans to offer five (5) digital bank licenses, and at least ten (10) institutions have stated their interest. They include Grab, Axiata Group Bhd, CIMB Group Holdings Bhd, Affin Bank Bhd, Hong Leong Bank Bhd, AMMB Holdings Bhd, Standard Chartered Bank Malaysia Bhd, Sunway Bhd, Green 


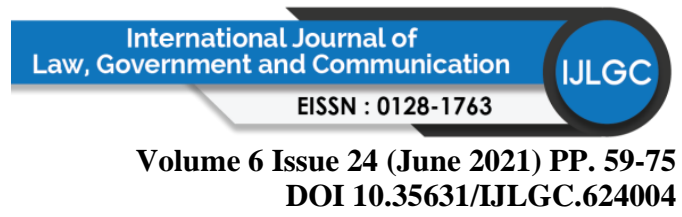

Packet Bhd, Razer Inc, AMTD Group, Paramount Corp Bhd, and MoneyLion Inc (The Edge Markets, 2020).

Notwithstanding the above, following Securities Commission Malaysia's introduction of a regulatory framework for peer-to-peer financing (P2P) (Securities Commission Malaysia, 2016), eleven P2P financing platform operators have registered with the Securities Commission Malaysia. They are B2B FinPAL Sdn Bhd, Bay Smart Capital Ventures Sdn Bhd, Capsphere Services Sdn Bhd, Crowd Sense Sdn Bhd, P2P Nusa Kapital Sdn Bhd, FBM Crowdtech Sdn Bhd, MicroLEAP PLT, Modalku Ventures Sdn Bhd, Moneysave (M) Sdn Bhd, Peoplender Sdn Bhd, and Quickash Malaysia Sdn Bhd. The digital platforms allow Small and Medium Enterprises to raise the required funds for working capital or growth (Securities Commission Malaysia, 2020).

Before the regulatory framework for P2P financing, the Securities Commission Malaysia announced a similar regulatory framework for equity crowdfunding (ECF) in 2015. The ECF regulatory framework, the first in the ASEAN region, enables newly set-up companies to seek early-stage financing (Securities Commission Malaysia, 2016). As of January 2021, ten (10) companies have received licenses from the Securities Commission Malaysia. The companies are Leet Capital Sdn Bhd, Ata Plus Sdn Bhd, Crowdo Malaysia Sdn Bhd, Eureeca SEA Sdn Bhd, FBM Corwdtech Sdn Bhd, Fundnel Technologies Sdn Bhd, MyStartr Sdn Bhd, Pitch Platforms Sdn Bhd, and Crowdplues Sdn Bhd.

Via the above initiatives, as of September 2020, RM 921.83 million has been raised for P2P financing with 13,039 successful campaigns and 2,502 issuers (Securities Commission Malaysia, 2021). For the same period, a total of RM 129.64 million amassed for ECF financing for 119 recipients raised from 113 funders.

\section{Insurance/Takaful}

The application of technologies in the insurance sector, also called insuretech, occurred in the sector's distribution channel, claim management, after-sales service, customization, and underwriting (IMF, 2020). Despite a slow start in embracing the technologies by the players (PWC, 2016), AXA Affin General Insurance Bhd and Tune Protect Group Bhd optimist insuretech will simplify daily business processes, and workflow hence improving efficiency and eventually result in innovative offerings meeting the customers' requirement (The Edge Markets, 2020). With insuretech, customers can purchase insurance coverage through mobile applications. Distribution channels are now extended to include affinity partnership and telemarketing.

Takaful operators in Malaysia have also embarked on initiatives to exploit technologies in their business operations. Takaful Malaysia Berhad, for example, has invested in tools, applications, and new technologies to enhance its operational efficiencies and expand customers' experience. Takaful Malaysia Berhad's customers now can access the operator's products online via its "Click for Cover" online sales platform (The Malaysian Reserve, 2018). Prudential BSN Takaful Berhad (PruBSN) has also stamped its commitment to digital transformation by unveiling its digital roadmap explaining the operator's digital activities (FinTech Magazine, 2020). They include strategic partnerships with fintech companies AccelTree Software Private Limited, Cyber Village Sdn Bhd, and DXC Technology Malaysia. PruBSN appointed AccelTree to develop a sales system point while Cyber Village built the 


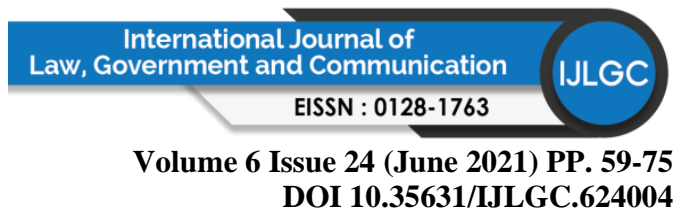

PruBSN customers' portal (FinTech Magazine, 2020). PruBSN's migrating customers' database developed by DXC Technology Malaysia would allow stability and efficiency. The move has resulted in an online, table-based point of sales system enabling PruBSN agents to serve customer's requirements instantly and effectively. The digitalization transformation has also allowed PruBSN to engage with potential customers through useful PruBSN Insan and Pulse applications. PruBSN Insan provides spiritual advice while Pulse offers users health management information.

\section{Investment Management}

Opportunities by leveraging technologies are the main motive behind asset management firms collaborating with fintech companies to provide robo-advisors or digital investment managers (DIM). The technologies provide new platforms for asset management firms to distribute their products. Using these platforms, investors can access unit trusts, purchase the units directly online, and build up their investment portfolios (The Edge Markets, 2020). Traditionally, investors depend on unit trust agents to buy unit trusts. Investors may opt for this method as the minimum required investment amount is lower plus a lower sales charge.

BIMB Investment Management Berhad, an asset management fund arm for Bank Islam Malaysia Berhad, has appointed Valuefy Solutions to develop BEST Invest application in 2020. Investors can depend on a robo-intelligence system for shariah and environmental, social, and corporate governance (ESG) investment. In the same year, Permodalan Nasional Berhad (PNB) has partnered with a fintech company Raiz Invest to build a micro-investing application. Eastspring Investments partnered with StashAway Malaysia, a robo-advisory platform, to operate a cash management solution (The Edge Markets, 2020). Malaysia's Employees' Provident Fund has also launched i-Invest in 2019 that allows its eligible members to invest their savings directly with the approved unit trust funds (EPF, 2020). Before the availability of $\mathrm{i}$-Invest, members can only invest via the approved unit trust funds.

\section{Market Support}

In addition to the above technologies that enable financial companies to digitize their products and services, other technologies are also crucial in digital financial transformation, such as electronic e-KYC, voluntary Open Application Interface (API), and cloud services. Open API allows fintech start-ups to develop applications and services for financial institutions. Cost elements are vital in digitalization, and cloud services reduce costs (IMF, 2020).

In summary, the financial industry's digitalization transformation, including Islamic Finance, offers enormous benefits to the financial industry generally and particularly for the Islamic Finance sector. The industry stakeholders have well-accepted the digitalization of Islamic Finance. Both Malaysia's financial regulatory bodies have been aggressive and dynamic with relevant regulatory frameworks, including relevant required policies to facilitate and stimulate the development of fintech solutions. The industry players are also quick to recognize the need to digitally transform their products and services, business operations, and other related activities.

Numerous reports are written highlighting the benefits, processes, and activities undertaken by the industry players to transform the industry, as presented above. Some researchers have also highlighted issues and challenges faced. Hussien (2019) highlighted obstacles and challenges blockchain posts to Islamic Finance, including regulatory challenges in general and without 


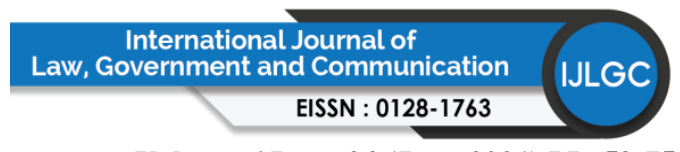

Volume 6 Issue 24 (June 2021) PP. 59-75

DOI 10.35631/IJLGC.624004

referring to any particular jurisdiction. His article did not include the analysis of shariah requirements concerning the changes required to the regulatory framework to incorporate the technology requirements. Referring to blockchain technology, he explained blockchain is based on the decentralized framework and forms a significant challenge for regulatory bodies to regulate. Hussien (2019) also highlighted the new technology's trust as it is an open system and clarified that regulators are familiar with the regulated trust providers.

Some Islamic Finance scholars have highlighted some of the legal and regulatory concerns about applying fintech in the Islamic Finance industry. Alam \& Zameni (2019) pointed to the risk of money laundering, terrorist financing, cybercrimes, tax fraud, consumer protection, and unclear rights. Additionally, the issues of data safety and security, personal privacy, and transparency were also bothersome by global governments. Referring to blockchain technology, the technology behind cryptocurrencies, they stated that it allows any person to own cryptocurrencies without any financial institutions' permission and can be sent to any individual with an e-wallet (citing Yeoh, 2017). They added regulatory authorities are uncomfortable with bitcoin and blockchain technology due to their decentralization nature, enabling and validating online transactions without intermediaries, including central bank Gassner \& Lawrence (2019). The scenario would also have regulatory and legal implications, particularly in the case of deposit-taking of the currency whereby licensing is required.

Another issue includes impracticability in adhering to cross-border transactions' regulatory requirements (Gassner et al., 2019). A critical feature of fintech is the use of smart contracts specifically applied in cryptocurrencies. Smart contracts refer to software that can also raise legal and shariah issues as they refer to software and codes (Gassner et al., 2019). The contracts are auto executed with multiple actions triggered by an external event and irreversible (Nienhaus, 2019). Legally, contracts refer to documents incorporating required terms and conditions of the transaction, signed and executed by all transacting legal person parties. In short, the question of whether smart contracts are valid legal contracts (Nienhaus, 2019). The auto-execution of smart contracts operated by artificial intelligence instead of a traditionally legal person. Nienhaus (2019) argued these post-specific legal issues, including liability of blockchain application developer's liability and third-party liability of the originators and users. As mentioned earlier, one technology employed in fintech is artificial intelligence. Gassner et al. (2019) highlighted that artificial intelligence is an artificial person instead of a legal person and may post a legal implication.

The above are some of the regulatory and legal issues concerning fintech and digitalization of Islamic Finance recorded by Islamic Finance scholars. This article, referring to Malaysia, will record more discussions on the same topics and expand the above researchers' discussions. The elaborated discussions will contribute to the knowledge of regulatory and legal issues in Islamic finance digitalization.

\section{Shariah Governance}

Compliance with shariah is the bedrock of Islamic Finance. It means all Islamic Finance business activities, practices, products, and services must meet the requirement set by the shariah (Central Bank of Malaysia, 2010). The requirements are documented in Shariah Standards and Operational requirements produced by Shariah Advisory Council and announced by the Central Bank of Malaysia (Shariah Advisory Council, 2020). 


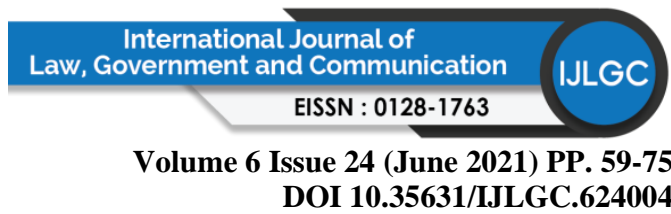

To ensure that all Islamic banks adhere to the shariah requirements in all of their business activities and practices, the Central Bank of Malaysia has issued Shariah Governance Framework in 2010 (Central Bank of Malaysia, 2010). The framework provides guidance for Islamic banks concerning respective Islamic bank's shariah governance. To enhance the efficiency of shariah governance, in 2020, the Central Bank of Malaysia has launched Shariah Governance Policy (SGP), replacing the Shariah Governance Framework (Central Bank of Malaysia, 2019). The SGP is legally supported with the enactment of the Islamic Financial Services Act (IFSA) 2013. Miskam \& Nasrul (2013) argued that IFSA 2013 has elevated shariah adherence requirements and, at the same time, observing regulatory and supervisory framework.

\section{Research Method}

This research employs a qualitative method using a library research approach by analysing past researchers conducted on the topic. The authors then elaborate on the findings in the following paragraphs.

\section{Legal Challenges for Digitalization of Banks}

Among the legal challenges are i) Embed shariah requirements, ii) Fraud and cybersecurity, and iii) Personal data protection.

"Shariazing" the digital bank process and our readiness for a shariah contract are always debated by the industry's players. This includes whether smart contracts meet the requirement of shariah. A digital signature, another feature of digitalization, has not been included in the SGP. Muhammad, Amboala, Mohd Salleh, Abdullah, Che Tahrim \& Che Nawi (2019) proposed digital signature in online transactions as an authentication mechanism. According to Johan, Dali, Suki \& Hafit (2017), digital signatures comply with an essential element of ijab and qabul for transacting parties.

To sustain the growth and development of the Islamic financial system and the industry's resilience is to be strengthened through evolving legal and regulatory reforms by the regulators (Zeti, 2013). The emergency of Islamic banking within the conventional banking system has been a great source of worry for scholars, policymakers, and regulators. The primary concern has to do with embedding shariah-compliant Islamic banking activities into the existing conventional financial system's juridical and supervisory frameworks (Heiko, Andreas \& Juan, 2008). Therefore, to address this issue, they adopted what was referred to as a two-tier perspective, for example, on the legal aspects of Islamic contracts and the regulatory aspects of Islamic financial transactions.

Although Islamic banking is in its growth and is recognized as a crucial integral part of the global financial system, its significant setbacks are the legal and regulatory challenges facing the financial industry (Cohan \& Cohan, 2011). The sought legal and regulatory reform may present a wide range of challenges to ensure more inclusive and sustainable growth. It is worthy to note that the Islamic financial industry is yet to develop a uniform legal and regulatory framework to support and enhance the Islamic financial system. Currently, Islamic countries' existing banking regulations are based on the conventional banking model. It is disconcerting to know that only a few of these countries have enacted specific laws to manage and regulate the Islamic banking and finance sector (Abiola, 2015). 


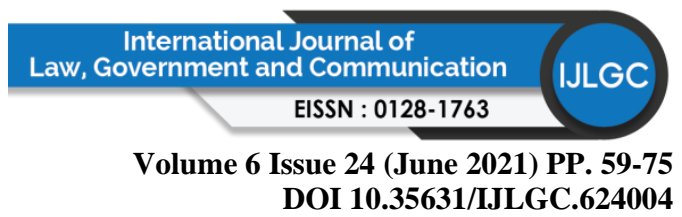

According to several studies on regulation and supervision of the Islamic banking system, strengthened legal and regulatory infrastructure through enhanced risk-based regulatory and supervisory framework can be achieved by the regulators and supervisors' prompt and pragmatic actions by taking the following steps: (Abiola, 2015).

i. Drafting Harmonized legislation and Regulation for Islamic Financial System.

Consistent legislation and regulation are essential to provide sustainable development and efficiency of the Islamic financial system. It will provide the impetus necessary for the sought total acceptance and complete integration of the Islamic banking system into the international financial system. However, Ahmad \& Mohsin (2014) argued that though this desires that the Islamic financial system's regulations should be aligned with conventional counterpart regulations, it should be done without compromising the Shariah requirements.

ii. Ensuring proper and adequate supervision to improve compliance and control system.

The regulatory and supervisory framework's focus should be on ensuring that the banking institutions adequately fulfill their compliance obligations through an effective and efficient control system. The compliance obligation, either in-terms of conventional or Islamic compliant, needs not to concentrate on the financial products' religious features but instead focus on instituting a risk-based regulatory framework (Nafis, 2012).

iii. Providing Reliable Islamic Financial Market Infrastructure.

It refers to the regulators and supervisors of Islamic financial institutions' ability to incorporate the international prudential standards into the Shariah structure of Islamic finance hence developing a harmonized risk-based regulatory framework for the industry and strengthen the financial market infrastructure.

iv. Building Customers' Confidence in Islamic Financial System.

Developing sound and robust regulatory/supervisory and governance frameworks allows market participants to have adequate information about their performance in this particular and the whole industry. Enhance corporate governance ensures that the most qualified Shariah scholars are selected to serve as members of the Shariah Supervisory Boards of Islamic financial institutions.

Another challenge is the risks of fraud in using digital banking through the falsification of the information and the possible manipulation of information stored in the digital database/electronic funds. Global technology specialist or GBG has revealed that Malaysian financial institutions face various fraud management challenges even as they continue to drive digital transaction growth. 54\% of Malaysian financial institutions foresee an increase in scams, whereas $51 \%$ expect more stolen ID cases. GBG collaborated with The Asian Banker 


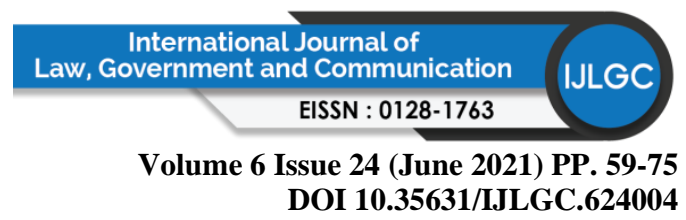

to survey 324 respondents from financial institutions (FI) in six Asia Pacific (APAC) countries, Australia, China, Malaysia, Indonesia, Thailand, and Vietnam.

More than $50 \%$ of financial institutions (FIs) in Malaysia see identity verification (58\%) and cyber fraud prevention (50\%) as key challenges in driving digital transaction growth, according to GBG, a specialist in fraud, identity verification, and location data intelligence.

It was reported that Malaysia experienced RM153 millions of losses because of cybercrimes in the first five months of 2019. About $47 \%$ of Malaysia's FIs indicated fraud detection while digitally onboarding new customers as the biggest challenge. The percentage is higher than the Asia Pacific (APAC) aggregate of 37\%, as revealed in GBG's inaugural report in Malaysia entitled Future-proofing Fraud Prevention in Digital Channels: Malaysia FI Study (The Sun Daily, October 13, 2020). For FIs in Malaysia, digital banking and cashless services have gone mainstream. They are pegged to overtake the average APAC rate of adoption this year, particularly e-banking, e-statements, and e-wallet services. The indicators reflecting Malaysia's growing digital lifestyle preference can be seen from their relatively high smartphone penetration at $78 \%$ and their internet infrastructure's readiness from the $80 \%$ penetration rate of their $4 \mathrm{G}$ networks. From the research, all fraud typologies from social engineering, first-party fraud, cyber-attacks, and anti-money laundering are projected to rise in 2020-2021. About 54\% of Malaysia's FIs expect an increase in scams and 51\% on stolen IDs.

The serious legal challenge is also surrounded by the potential conflict of faith and intellectual property of information captured involving the third-party relationship, technology and software services providers, and the related items regarding digital banking such as electronic signature, digital and electronic-money, and customer privacy. The banking industry is one the industries that commonly ask customers for their personal details and data, so much so there would not exchange personal data as one of the core activities in the banking sector. Apart from the bank, the retail industry, the educational system, government agencies, and health organizations are also among the industries that actively collect, use and disseminate personal data (Earp \& Payton, 2006.; Phelps, Nowak \& Ferrell, 2000).

Malaysia's first comprehensive personal data protection legislation, the Personal Data Protection Act 2010 (PDPA), was passed by the Malaysian Parliament on June 2, 2010, and came into force on November 15, 2013. The definition of personal data is that: 'Personal data' means any information in respect of commercial transactions that is: Being processed wholly or partly by means of equipment operating automatically in response to instructions given for that purpose Recorded with the intention that it should wholly or partly be processed by means of such equipment, or Recorded as part of a relevant filing system or with the intention that it should form part of a relevant filing system, and, in each case ... that relates directly or indirectly to a data subject, who is identified or identifiable from that information or from that and other information in possession of a data user. Personal data includes any sensitive personal data or expression of opinion about the data subject. Personal data does not include any information processed for a credit reporting business carried on by a credit reporting agency under the Credit Reporting Agencies Act 2010.

As businesses expand and technology advances, banks have widened their product and services to the public to include mobile banking, internet banking, credit and debit cards, auto-pay, and online shopping (Akhisar, Tunay \& Tunay, 2015; Mokhlis, 2009). These activities directly or 


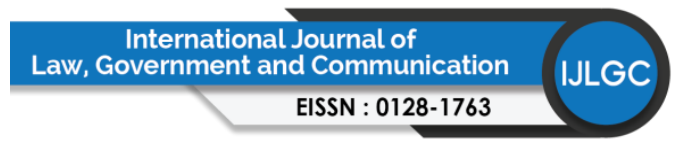

Volume 6 Issue 24 (June 2021) PP. 59-75

DOI 10.35631/IJLGC.624004

indirectly ask customers to disclose their personal data on almost every transaction for "official purpose" before their transaction could be processed. This has also excessively increased the banks' burden to invest in tightening their data security to safeguard and protect the customers' personal data from any data breach. These activities are associated with data misuse, data abuse, and data theft (Schermer, 2011). The above problem's seriousness could be mapped from numerous previous studies in personal data protection areas (King \& Raja, 2012; Ariff, Yun, Zakuan \& Ismail, 2013).

As observed by (Ong, 2012), there is no specific guidance under PDPA specifically on the method of obtaining customer consent, whether it is oral, written, or implied. The legal silence may open an opportunity for irresponsible data users to abuse customers' ignorance or trust to gather and sell the information to third parties like retailers or marketers at a specific price for their benefits. In this context, it is essential to determine whether banks indeed, as data users, comply with the legal requirements of PDPA in dealing with personal data and, if so, to what extent they protect the privacy and interests of data subjects in their commercial transactions (Mohamed Yusof et al., 2016).

\section{Enabling Legal Framework: Malaysia Experience}

Malaysia's Islamic financial system has been regarded as one of the world's most comprehensive systems (Lajis, Ismath Bacha \& Mirakhor, 2015). The Islamic banking industry's growth and development are supported through goods governance and its comprehensive legal frameworks. Malaysia's approach to the regulation of Islamic finance is an integrated one. While its specific legal structures govern the Islamic financial system, it is also subject to many regulations almost the same as those of the conventional system with which it exists side by side.

The primary regulation in the financial system is the Central Bank of Malaysia Act 1958, now repealed by the Central Bank of Malaysia Act 2009 (CBMA) which to provide for the continued existence of the Central Bank of Malaysia and the administration, objects functions, and powers of the central bank, for consequential or incidental matters. Together with other banks and financial institutions carrying out Islamic banking business, Islamic banks are under the Central Bank of Malaysia's authority and supervision. The legal basis for the Islamic banking business operation in Malaysia primarily consists of Islamic Banking Act 1983 (IBA) and the Banking and Financial Institutions Act 1989 (BAFIA). The IBA 1983 and BAFIA 1989 have been replaced by the Islamic Financial Services Act 2013 (IFSA) and Financial Services Act 2013 (FSA). The IBA 1983 provides for the regulation and supervision of Islamic financial institutions, payment systems, and other relevant entities and the oversight of the Islamic money market and Islamic foreign exchange market to promote financial stability and compliance with shariah and related consequential or incidental matters. While BAFIA provides for the regulation and supervision of financial institutions, payment systems, and other relevant entities and the money market and foreign exchange market's oversight to promote financial stability and related consequential or incidental matters.

Despite these three principal regulations governing the financial systems, other relevant laws such as Contracts Act 1950, National Land Code, Hire Purchase Act 1967, Unclaimed Moneys Act 1965, and others. For instance, the Contracts Act 1950 applies to any transaction involving a contract, including a contract in Islamic banking and finance cases. There are several elements for a valid contract applicable in the Islamic contract: offer, acceptance, consideration, free 


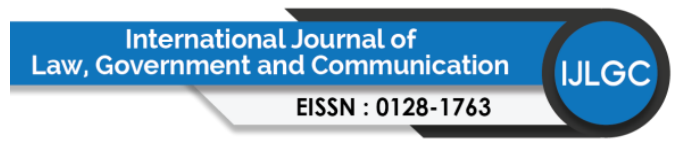

Volume 6 Issue 24 (June 2021) PP. 59-75

DOI 10.35631/IJLGC.624004

consent, legal capacity, and intention to create legal relation. Whereas in Islam, the elements of a contract are parties, sighah, and subject matters.

\section{Legal Framework: Enabling Laws}

Malaysia has a unique legislative framework consisting of mixed jurisdictions and mixed legal systems, namely the common law and shariah. As Malaysia is one of the common law countries, it is essential to have standard law of practice, which harmonizes both shariah and civil law. The integration of these two traditions is necessary for the context of Islamic banking in Malaysia.

As to be noted, Malaysia operates a dual banking system, namely a conventional banking system operating in tandem with an Islamic banking system. The Central Bank of Malaysia is empowered to act as the regulator and authoritative body with a comprehensive legal power to regulate and supervise its financial system. Islamic banks and Malaysian conventional banks are under the supervision and regulation of the Central Bank of Malaysia. Hence, the financial system's primary regulation is the Central Bank of Malaysia Act 1958, now repealed by the Central Bank of Malaysia Act 2009 (CBMA). Together with other banks and financial institutions carrying out Islamic banking business, Islamic banks are under the Central Bank of Malaysia's authority and supervision.

The concept of corporate governance from the Islamic perspective is to ensure shariah compliance. Shariah governance framework within IFIs enforces the credibility of shariah compliance. The framework raises investors and the public's confidence in the authenticity of Islamic banking's conduct and practice and minimizes fiduciary and reputational risks to IFIs. A useful governance framework for IFIs promotes greater transparency and a higher disclosure level to address different stakeholders' asymmetry in a different structure of Islamic finance transactions. It should ensure that all relevant stakeholders must be treated fairly, including minority shareholders and investment account holders of the banking industry. Shariah governance framework should have a conscious application of the goals and objectives of shariah (maqasid shariah), where legal and regulatory requirements must have ethical or socially responsible outcomes to ensure justice and equitable of stakeholders (Yusof \& Humeid AlHarthy, 2013).

Shariah supervisory board is an integral organ of the Islamic banking and financial system. It is the responsibility of a shariah board to approve and validate an Islamic bank's contracts products and services. However, the central role of the shariah supervisory boards is consultative and not supervisory. The Islamic banking industry is yet to develop and accustom itself to its products and services' real supervision. Theoretically, there is an internal shariah audit, but practically it is not carried out and implemented as per requirements. The organizational structure of the Islamic financial industry is developed in a way that the focus is to earn more even at the cost of shariah compliance. Retaining the supremacy of the shariah principles would attain confidence. It is important to note that the existence of a shariah supervisory board is to ensure shariah compliance in all aspects of an Islamic bank (Inam Ullah Khan, 2013, 176-177)

The Islamic Financial Services Board (IFSB) has been established to promote Islamic financial institutions' regulatory framework. IFSB is an international organization that issues standards 


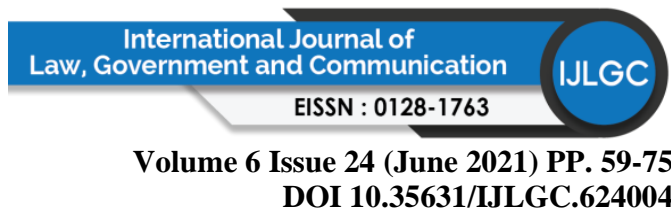

for Islamic banking, insurance (takaful), and capital market sectors. The primary purpose is to promote stability in the Islamic financial services industry.

The Accounting and Auditing Organisation of Islamic Financial Institutions (AAOIFI) is an institute that introduces standards for the establishment and operation of the shariah supervisory boards. This is a significant achievement concerning shariah governance and compliance in the Islamic banking and financial industry. AAOIFI standard with regards to shariah governance is a guideline and needs to be complied with in the Islamic banking and financial industry. Non-compliance with the AAOIFI standard will expose the industry to fiduciary and reputational risks (Inam Ullah Khan, 2013, 176-177) Therefore, implementing the AAOIFI's standard is one of the outstanding issues and needs further consideration as most Islamic financial institutions do not follow these standards as required. However, AAOIFI does not have the power to implement its standards. It would be more appropriate that the Islamic Financial Services Board (IFSB) should be provided with such powers to implement AAOIFI's standards in Islamic financial institutions. IFSB follows a due process for implementing its standards as it is the responsibility of the representative of a member country to implement the IFSB standard in his own country. It will help harmonize the shariah injunctions as a uniform standard will be followed in the Islamic banking and financial industry.

\section{Legal Framework: Dispute Resolution Mechanisms}

Malaysia has a dual court system which is the civil court system and the shariah court system. The Malaysian legal system is based on the common law system. Following the common law system, the courts abide by the precedent's doctrine, leading to the law's consistency and certainty (Mohamad, 2013). The jurisdiction of shariah courts is laid down in paragraph 1 of the State List in the Ninth Schedule of the Federal Constitution. It states that the shariah courts shall have jurisdiction only over persons professing the religion of Islam and in respect of any of the matter of Islamic law and personal family law of persons professing the religion of Islam. The shariah courts shall have no jurisdiction regarding offenses except in so far as conferred by federal law.

According to Oseni \& Ahmad (2015), Malaysia's legal system has undergone many reforms to ensure there is no dispute. In Malaysia, bank customers will ultimately prefer consumerfriendly financial institutions, especially in dispute management. Regulatory authorities such as the Central Bank of Malaysia have challenges regarding the contract agreement.

As an alternative to court litigation and the growing dissatisfaction against the court process, processes classified as Alternative Dispute Resolution (ADR) were developed. In other words, to overcome the over formalistic legal processes introduced by the court system, alternative avenues for amicable dispute settlement that would ensure and sustain the relationship between the parties were introduced. In the field of consensual settlement of disputes with little or no aid from the conventional court system, ADR emerged as a discipline in the $20^{\text {th }}$ century. In its broad sense, ADR can be defined as a means of processes or procedures of settling disputes privately and amicably other than traditional litigation. Any of such processes involving a thirdparty neutral appointed to affect an amicable settlement qualifies as an ADR process. These include negotiation, mediation, arbitration, conciliation, and ombudsman (Abdul Hak, Oseni $\&$ Mohamed, 2016). 


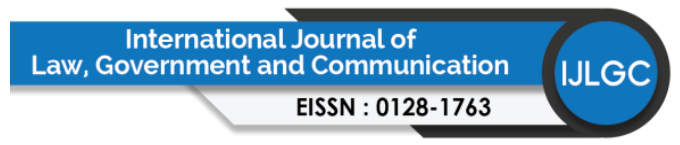

Volume 6 Issue 24 (June 2021) PP. 59-75

DOI 10.35631/IJLGC.624004

Generally, arbitration can be defined as "the process by which a dispute or difference between two or more parties as to their mutual legal rights and liabilities is referred to and determine judicially and with binding effect by the application of the law by or more persons (the arbitral tribunal) instead by a court of law." In other words, arbitration is a relatively public, formal coercive, and adversarial process. It is a determinative process where the third party determines a fair solution to the conflict on the opposing positions' merits. Unlike mediation, in arbitration, the third party imposes a solution. The award as a decision of the arbitral tribunal includes any final interim or partial award and any award on costs or interest but does not include interlocutory orders.

Mediation or known as sulh in Islam is a process to facilitate disputing parties with a third party's assistance who acts as a mediator in their dispute. In mediation, this third party has no power to impose a settlement on the parties, who retain authority for making their own decision. In helping the parties, negotiate a resolution of their dispute by agreement, the mediator uses specific procedures, techniques, and skills. In most cases, the mediation process ends with the review stage. In some cases, the mediator may arrange a follow-up appointment to review the outcomes of mediation. If the parties record their settlement agreement as an order of a court or if the mediator is appointed an arbitrator to issue a consent award, the settlement is immediately enforceable, and a court may provide summary judgment.

Ombudsmen have revolutionized remedial grievance procedures in most institutions, whether government or private. In curbing such a menace, the ombudsman was introduced. Ombudsman is a person or an office appointed or established by the government of a private entity charged with proactively addressing complaints, disputes, and misunderstandings relating to maladministration. The new trend which came to the limelight in the early 1990s is the private sector initiatives to employ the ombudsman to ensure customer protection through proper complaint handling. This is often treated as an 'in-house' corporate dispute management mechanism in which any party who is dissatisfied can file a formal complaint to the ombudsman.

There are numerous legal texts in the Quran and the Sunnah that establish the significance of amicable dispute settlement. The verse of the Quran as in Surah An-Nisa, "If you fear a breach between them twain (the man and his wife), appoint (two) arbitrators, one from his family and the other from her's; if they both wish for peace, Allah will cause their reconciliation. Indeed, Allah is ever All-knower, well-acquainted with all things" (Qur'an, 4:35). Similarly, the Sunnah provides several historical precedents on the amicable settlement of disputes laid down by the Prophet. The Prophet said: He who makes peace (through mediation) between the people by inventing good information or saying good things is not a liar. (al-Bukhārī, 12692, 3:209, Hadith no. 857). Thus, it is clear from the Quran and Sunnah's verse emphasizes amicable settlement of disputes while ensuring justice, fairness, and equity in all situations (Abdul Hak et al., 2016).

\section{Summary and Conclusion}

It is challenging to deny various technological inventions that science has brought into our lives in the information age. With the rapid growth of electronic, mostly Internet-based services, there has been increased interest in e-banking services and has become one of the advanced technologies. Incorporating core elements of digitalization in shariah governance is essential for Islamic financial institutions to ensure the business operation is following shariah. Since 


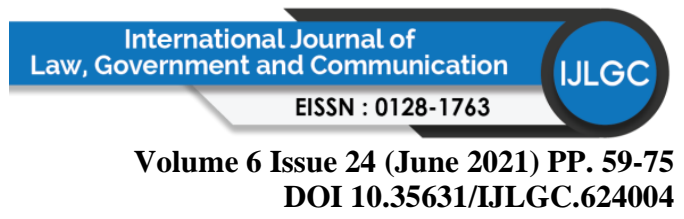

Islamic banking develops tremendously and contributes to the current economy, shariah governance needs special attention not only to meet the needs and interests of people's lives, even to cultivate the well-being of the ummah.

Incorporating digitalization elements requires sufficient knowledge of the applied technologies by the shariah scholars. The knowledge is vital for the shariah scholars to upgrade the existing Shariah Governance Policy and determine the shariah compliance of Islamic banks operations and activities concerning fintech. Hence shariah scholars, particularly those appointed as Shariah Advisors in Islamic banks' shariah committees and the Shariah Advisory Council of Central Bank of Malaysia.

In addition to reviewing Shariah Governance Policy and the Shariah Standards and Operational, decision-makers and policymakers must improve existing policies, laws, and regulations by embedding the shariah requirements to get fraud and cybersecurity environment and personal data protection issues minimized and well protected. The efforts will help protect individuals from any biased contracts or agreements and create a more efficient and conducive environment for e-commerce and online transactions. In case of legal issues brought to the relevant courts, the jurisdiction process's remedial must also be investigated.

\section{References}

Abiola. S. (2015) Legal and Regulatory Issues and Challenges Inhibiting Globalization of Islamic Banking System, IIUM Institute of Islamic Banking and Finance (IIiBF) Malaysia February 23, 2015, https://mpra.ub.uni-muenchen.de/62332/ (retrieved on December 10, 2020).

Ab Razak, M. I., Mohd Dali, N. A. \& Abdull Manaf A. W. (2019). Embracing New World of Islamic Fintech in Malaysia: Moving Towards Digitalisation Era. Presented at the 9th International Economics and Business Management held at The Imperial Heritage Hotel Melaka, Malaysia.

Abdul Hak, N., Oseni, U. A. \& Mohamed, N. S. (2016). Comparative Perspectives on Alternative Dispute Resolution: With reference to Malaysia. IIUM Press.

Ahmad, A. \& Mohsin, I. (2014). How Greater Regulation will Lead to Islamic Finance Growth in Qatar. Al-Mirsal, January 21, 2015. http://www.almirsal.com/2014/01/29/howgreater-regulation-will-lead-to-islamicfinance-growth-in-qatar/ (retrieved on December 10, 2020).

Akhisar, I., Tunay, K. B. \& Tunay, N. (2015). The Effects of Innovations on Bank Performance: The Case of Electronic Banking Services. Procedia - Social and Behavioral Sciences 195, 369-375.

Alam, N. \& Zameni, A. (2019). The Regulation of Fintech and Cryptocurrencies. Oseni, U. A. \& Ali, S. N. Fintech in Islamic Finance: Theory and Practice. Routledge. (pg. 159 173).

Al Quran. https://corpus.quran.com/translation.jsp?chapter $=4 \&$ verse $=35$

Al-Bukhārī. 12692, 3:209, Hadith no. 857

Ariff, M.S.M., Yun, L. O., Zakuan, N. \& Ismail, K. (2013). The Impacts of Service Quality and Customer Satisfaction on Customer Loyalty in Internet Banking. Procedia - Social and Behavioral Sciences 81, 469-473.

Central Bank of Malaysia (2010). Shariah Governance Framework for Islamic Financial Institutions 
Central Bank of Malaysia (2019). http://www.bnm.gov.my/index.php?ch=en_speech\&pg=en_speech\&ac=819\&lang=b $\mathrm{m}$

Cohan, M. N. \& Cohan, M. W. (2011) “Analysis of Law Relating to Establishment of Banking Courts in Pakistan.” Pakistan Law Journal (PLJ), 25 - 32.

Earp, J. B. \& Payton, F. C. (2006). Information Privacy in the Service Sector: An Exploratory Study of Health Care and Banking Professionals. Journal of Organizational Computing and Electronic Commerce 16(2),105-122.

Gassner, M. \& Lawrence, J. (2019). Fintech In Islamic Finance: Business models and the need for legal solutions. Oseni, U. A. \& Ali, S. N. Fintech in Islamic Finance: Theory and Practice. Routledge, pp. 174 - 182.

Global Islamic Finance Report 2020

IMF Country Report No 20/58, 2020

Inam Ullah Khan. (2013). "Legal and Regulatory Framework of Islamic Banking," in Islamic Transactions and Finance: Principles and Developments, eds. Mohammad Hashim Kamali and Sheila Ainon Yussof (Kuala Lumpur: Malaysian Current Law Journal Sdn. Bhd. and International Institute of Advanced Islamic Studies, 2014), 176-177.

Heiko, H., Andreas J. \& Juan S. (2008). Trends and Challenges in Islamic Finance. World Economics. Vol. 9, No.2, April-June 2008.

Hussien, E. (2019). Blockchains for Islamic finance: Obstacles \& Challenges. MPRA Paper 92676, University Library of Munich, Germany

https://www.bnm.gov.my/index.php?ch=en_speech\&pg=en_speech\&ac=861\&lang=bm\#gsc.t $\mathrm{ab}=0$

https://www.cxotoday.com/news-analysis/role-of-fintech-in-the-digital-economy/

https://fintechnews.my/24197/digital-transformation/ekyc-malaysia-guideline-bnm/

https://www.fintechmagazine.com/company/prubsn-creating-digital-roadmap-insurance-40

https://www.kwsp.gov.my/member/investment

https://www.lexology.com/library/detail.aspx?g=90b6fb34-708d-4671-ab5d-

943cbdafdf5b\#: :text=Together\%20with\%20the $\% 20$ issuance $\% 20$ of,the $\% 20$ first $\% 20 \mathrm{q}$ uarter\%20of\%202022.

https://mdec.my/

https://www.nst.com.my/business/2018/04/353950/rhb-islamic-will-introduce-e-commercefinancing-platform

https://www.pwc.com/my/en/publications/insurtech-the-road-ahead.html

https://www.sc.com.my/development/digital/list-of-registered-recognized-market-operators

https://www.sc.com.my/resources/media-releases-and-announcements/sc-introducesregulatory-framework-to-facilitate-peer-to-peer-financing

https://themalaysianreserve.com/2018/01/29/takaful-malaysia-leverage-digitalisation-highreturns/

https://www.theedgemarkets.com/article/insurance-insurtech-makes-headway-localmarkethttps://techbarrista.com/bank-islam-undergo-digital-

transformation/\#: :text=Digitalisation\%20will\%20help\%20Bank\%20Islam,overcomi ng\%20cost $\% 20$ and $\% 20$ physical\%20barriers.

https://www.thestar.com.my/business/business-news/2020/02/18/bank-islam-to-offer-digitalproducts

https://www.thesundaily.my/business/malaysian-financial-institution_(retrieved on December 10, 2020).

https://www.theedgemarkets.com/article/interest-digital-bank-licences-picks 


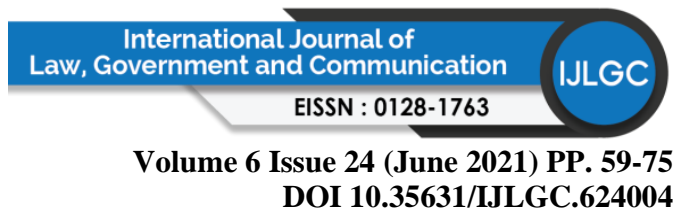

https://www.theedgemarkets.com/article/thewall-fintech-and-asset-management-firmsdisrupting-fund-distribution

Johan, Z. J., Dali, N. R. S. M., Suki, A. A., \& Hafit, N. I. A. (2017). Customers' intention towards Shariah-compliant credit cards: A pilot study. International Journal of Academic Research in Business and Social Sciences, 7(4), 772-799. https://doi.org/10.6007/IJARBSS/v7-i4/2887

King, N. J. \& Raja, V. T. (2012). Protecting the privacy and security of sensitive customer data in the cloud. Computer Law and Security Review 28(3), 308-319.

Lajis, S. M, Ismath Bacha, O. \& Mirakhor, A. (2015). Regulatory Framework for Islamic Finance: Malaysia's Initiative.

Miskam, S., \& Muhammad Amrullah, N. (2013). Shariah Governance in Islamic Finance: The Effects of the Islamic Financial Services Act 2013. Paper presented at the World Conference on Integration of Knowledge (WCIK) 2013, Langkawi, Malaysia.

Mohamed Yusof, N. A, Ahmad, N. A. \& Mohamed, Z. (2016). A Study on Collection of Personal Data by Banking Industry in Malaysia, Journal of Advanced Research in Business and Management Studies ISSN (online): 2462-1935 | Vol. 2, No. 1. 39-49.

Mokhlis, S. (2009). Commercial Bank Selection: Comparison between Single and Multiple Bank Users in Malaysia. International Journal of Economics and Finance 1, 263- 273.

Muhammad, M. Z., Amboala, T., Mohd Salleh, M. Z., Abdullah, A., Che Tahrim, S. N. \& Che Nawi, N. (2019). The Application of Shariah Principle in E-commerce Transaction: A Model Development. Research in World Economy. Vol. 10, No. 2; Special Issue, 2019

Nafis, A. (2012). Impact of Regulatory and Supervisory Structures on Bank Risk and Efficiency: Evidence from Dual Banking System. Asian Journal of Finance \& Accounting. Vol. 4, No. 1. July 1, 2012.

Nienhaus, V. (2019). Blockchain Technologies And The Prospects Of Smart Contracts In Islamic Finance. Oseni, U. A. \& Ali, S. N. Fintech in Islamic Finance: Theory and Practice. Routledge. 183 - 214

Ong, R. (2012). Data protection in Malaysia and Hong Kong: One step forward, two steps back? Computer Law \& Security Review 28(4), 429-437.

Oseni, U. A., \& Ahmad, A. U. F. (2015). Dispute resolution in Islamic finance: A case analysis of Malaysia. Ethics, Governance and Regulation in Islamic Finance, 125.

Phelps, J., Nowak, G. \& Ferrell, E. (2000). Privacy Concerns and Consumer Willingness to Provide Personal Information. Journal of Public Policy \& Marketing 19(1), 27-41.

Schermer, B. W. (2011). The limits of privacy in automated profiling and data mining. Computer Law and Security Review 27(1), 45-52.

Shariah Advisory Council (2020). http://www.sacbnm.org/?page_id=3318

Zeti, A. A. (2013). Islamic Finance - The New regulatory Challenge. Introductory Remark at the Book Launch of Islamic Finance - The New Regulatory Challenge, 2nd edition, Kuala Lumpur. July 22, 2013. 